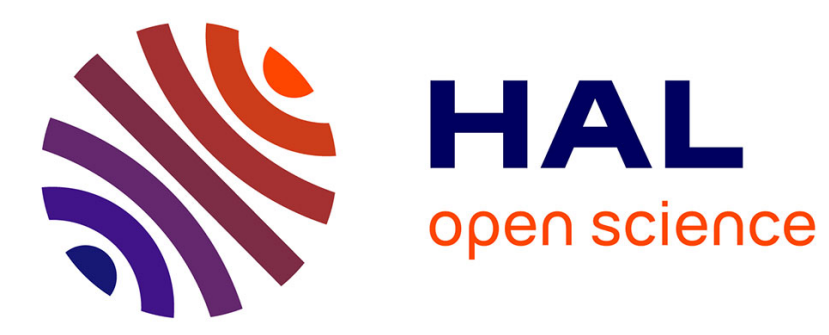

\title{
Radical solution copolymerisation of vinylidene fluoride with hexafluoropropene
}

\author{
Bruno Ameduri, Marie Pierre Gelin
}

\section{To cite this version:}

Bruno Ameduri, Marie Pierre Gelin. Radical solution copolymerisation of vinylidene fluoride with hexafluoropropene. Journal of Fluorine Chemistry, 2005, 126, pp.577-585. 10.1016/j.jfluchem.2004.12.010 . hal-00382631

\section{HAL Id: hal-00382631 \\ https://hal.science/hal-00382631}

Submitted on 9 May 2009

HAL is a multi-disciplinary open access archive for the deposit and dissemination of scientific research documents, whether they are published or not. The documents may come from teaching and research institutions in France or abroad, or from public or private research centers.
L'archive ouverte pluridisciplinaire HAL, est destinée au dépôt et à la diffusion de documents scientifiques de niveau recherche, publiés ou non, émanant des établissements d'enseignement et de recherche français ou étrangers, des laboratoires publics ou privés. 


\title{
Radical solution copolymerisation of vinylidene fluoride with hexafluoropropene
}

\author{
Marie-Pierre Gelin, Bruno Ameduri* \\ Laboratoire de Chimie Macromoléculaire, UMR CNRS 5076, Ecole Nationale Supérieure de Chimie de Montpellier, \\ 8, Rue Ecole Normale, 34296 Montpellier Cedex 05, France
}

Received 16 September 2004; accepted 31 December 2004

Available online 30 January 2005

Dedicated to our friend Dick Chambers in honour of his 70th birthday.

\begin{abstract}
The radical copolymerisation in solution of vinylidene fluoride (or 1,1-difluoroethylene (VDF)) with hexafluoropropylene (HFP) initiated by di-tert-butyl peroxide is presented. A series of eight copolymerisation reactions was investigated with initial $[\mathrm{VDF}]_{\mathrm{o}} /[\mathrm{HFP}]_{\mathrm{o}}$ molar ratios ranging from 5.0/95.0 to 85.2/14.8. Both co-monomers copolymerised in this range of copolymerisation. Moreover, only VDF homopolymerised in these conditions. The copolymer compositions of these random-type copolymers were calculated by means of ${ }^{19} \mathrm{~F}$ NMR spectroscopy which allowed the respective amount of each monomeric unit in the copolymer to be quantified. The Tidwell and Mortimer method led to the assessment of the reactivity ratios, $r_{i}$, of both co-monomers showing a higher incorporation of VDF in the copolymer $\left(r_{\mathrm{HFP}}=0.12 \pm 0.05\right.$ and $r_{\mathrm{VDF}}=2.9 \pm 0.6$ at $\left.393 \mathrm{~K}\right)$. Alfrey-Price's $Q$ and $e$ values of HFP were calculated to be 0.002 (from $Q_{\mathrm{VDF}}=0.008$ ) or 0.009 (from $Q_{\mathrm{VDF}}=0.015$ ) and +1.44 (versus $e_{\mathrm{VDF}}=0.40$ ) or +1.54 (versus $e_{\mathrm{VDF}}=0.50$ ), respectively, indicating that HFP is an electron-accepting monomer. The thermal properties of these fluorinated copolymers were also determined. Except for those containing a high amount of VDF, they were amorphous. Each showed one glass transition temperature $\left(T_{\mathrm{g}}\right)$ only, and from known laws of $T_{\mathrm{g}}$, that of the homopolymer of HFP was assessed. It was compared with that obtained from the literature after extrapolation and is discussed.
\end{abstract}

(C) 2005 Elsevier B.V. All rights reserved.

Keywords: Copolymerisation; Vinylidene fluoride; Hexafluoropropylene; Reactivity ratio; NMR analysis; Microstructure; Glass transition temperature

\section{Introduction}

Radical copolymerisations of fluorinated monomers with hydrogenated or fluoroolefins have recently been reviewed [1]. In the case of the copolymerisation of vinylidene fluoride (1,1-difluoroethylene), VDF, numerous investigations have been performed with non-halogenated $[2,3]$ or fluorinated co-monomers $[1,4,5]$. Among them, hexafluoropropylene (HFP) has already led to commercially available thermoplastics [6] (Table 1), elastomers [7] (Table 2) or thermoplastic elastomers $[1,7,8]$, since the discovery of

\footnotetext{
* Corresponding author. Tel.: +33 467144368; fax: +33467147220 .

E-mail address: ameduri@enscm.fr (B. Ameduri).
}

poly(VDF-co-HFP) copolymers in 1957 by Du Pont de Nemours company [9]. These copolymers are produced on an industrial scale by Du Pont, Solvay Solexis, 3M/Dyneon, Daikin and Atofina (now Arkema). They are endowed with good thermal properties and chemical inertness to acids and petroleum and have found numerous applications in various fields such as automobiles, space, aeronautics, electronics and engineering.

The kinetics of copolymerisation of VDF with HFP have been studied by Moggi et al. [10] and by Pianca et al. [11] under emulsion polymerisation. However, kinetics was not carried out in solution.

The objectives of this paper are to revisit the radical copolymerisation of VDF with HFP in solution and in batch. 
Table 1

Main commercially available VDF-containing thermoplastics (HFA stands for hexafluoroacetone)

\begin{tabular}{|c|c|c|c|c|}
\hline Monomers & Composition $(\mathrm{mol} \%)$ & Trade name & Producer & Melting point $\left({ }^{\circ} \mathrm{C}\right)$ \\
\hline \multirow[t]{3}{*}{ VDF/CTFE } & $90 / 10$ or $95 / 5$ & FORAFLON $^{\circledR}$ & Arkema & $165-167$ \\
\hline & id. & KF POLYMER ${ }^{\circledR}$ & Kureha & - \\
\hline & & SOLEF $^{\circledR}$ & Solvay Solexis & $150-165$ \\
\hline VDF/TFE & $80 / 20$ & KYNAR $^{\circledR}$ SL, 7299 & Arkema N.A. & 120 \\
\hline VDF/HFA & $88 / 12$ & - & Central Glass & 121 \\
\hline \multirow[t]{2}{*}{ VDF/HEP } & $95 / 5$ or $85 / 15$ & KYNARFLEX $^{\circledR}$ & Arkema N.A. & $135-160$ \\
\hline & & SOLEF $^{\circledR}$ & Solvay Solexis & $130-160$ \\
\hline VDF/TFE/HFP & $72 / 18 / 10$ & $\mathrm{KYNAR}^{\circledR} \mathrm{ADS}$ & Arkema N.A. & 90 \\
\hline VDF/TFE/HEP & $30 / 55 / 15$ & HOSTAFLON $^{\circledR}$ & Dyneon & $160-185$ \\
\hline (VDF/CTFE)-g-VDF & $(37.5 / 12.5) / 50$ & CEFRALSOFT $^{\circledR}$ & Central Glass & 170 \\
\hline
\end{tabular}

Table 2

Main commercial VDF-containing elastomers

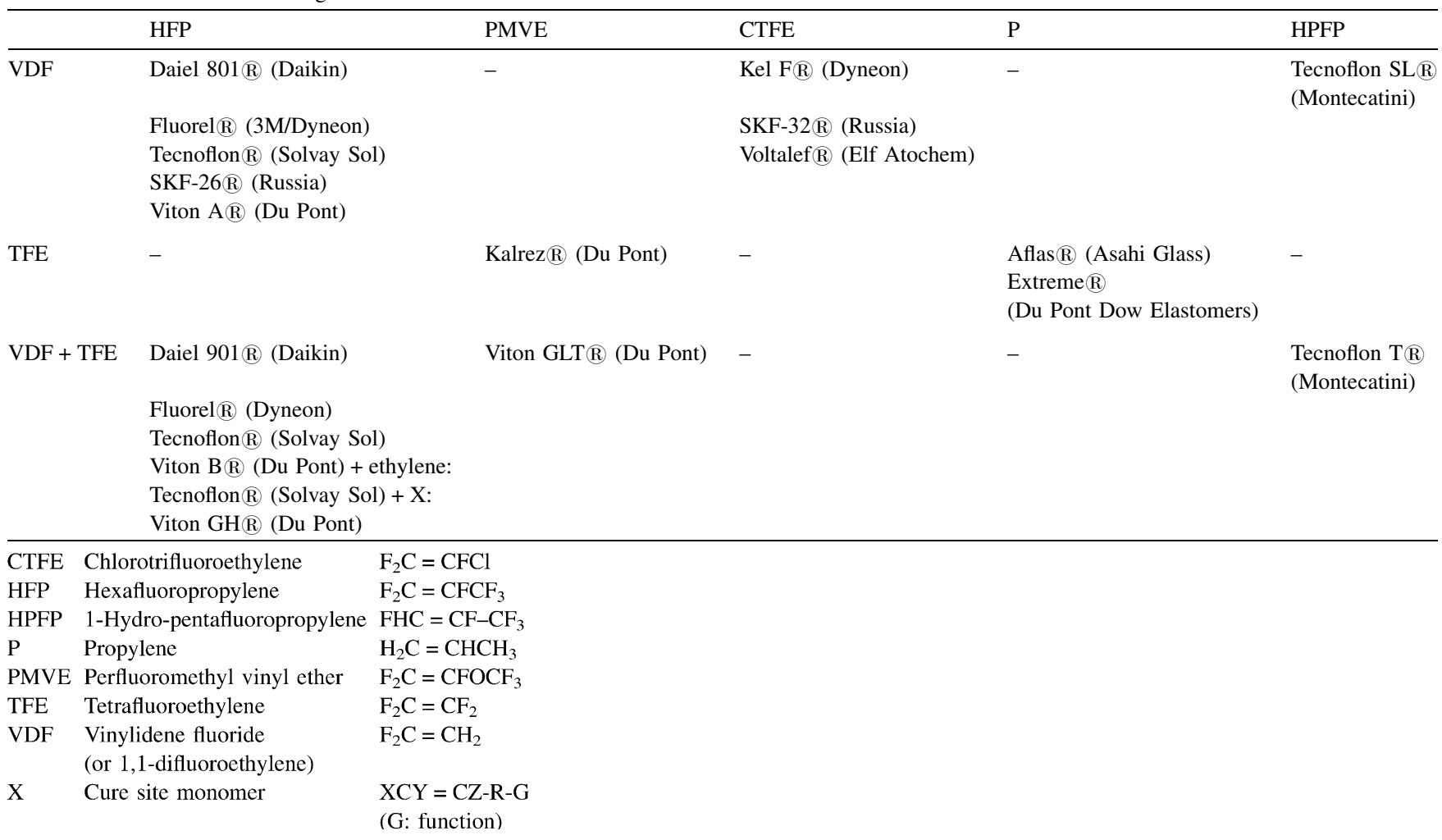

A kinetic approach enabled us to assess the reactivity ratios of both co-monomers and to compare them with those in the literature; then, the thermal properties (especially glass transition temperatures) of these fluorocopolymers have been investigated.

\section{Results and discussion}

The radical copolymerisation of vinylidene fluoride (VDF) with hexafluoropropylene (HFP) was performed in batch and in solution (in acetonitrile), initiated by di-tertbutyl peroxide at $393 \mathrm{~K}$ for about $10 \mathrm{~h}$, as follows:

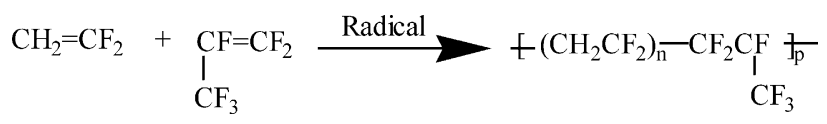

At $393 \mathrm{~K}$, half-life of the organic peroxide was ca. $6 \mathrm{~h}$. Acetonitrile was chosen as solvent because it solubilises both fluoroalkenes and does not generate much transfer [12]. Because both co-monomers are gaseous (b.p. of VDF and HFP are 191 and $245 \mathrm{~K}$ at atmospheric pressure, respectively), the copolymerisation reactions of VDF with HFP were carried out in an autoclave or in thick Carius tubes. Eight experiments were carried out under these conditions assuming that ca. 10-12\% of VDF was converted; the results are listed in Table 3. 
Table 3

Experimental results of the radical copolymerisation of VDF with HFP at $393 \mathrm{~K}$ (initiated by di-tert-butyl peroxide)

\begin{tabular}{lllll}
\hline $\begin{array}{l}\text { Experiment } \\
\text { no. }\end{array}$ & $\begin{array}{l}\text { Mol.\% } \\
\text { VDF } \\
\text { (in feed) }\end{array}$ & $C_{0}(\%)$ & Time (h) & $\begin{array}{l}\text { Mol.\% } \\
\text { VDF in the } \\
\text { copolymer }\end{array}$ \\
\hline 1 & 85.2 & $1.2 \times 10^{-3}$ & 11 & 93.7 \\
2 & 75.0 & $1.1 \times 10^{-3}$ & 10 & 89.3 \\
3 & 69.3 & $1.0 \times 10^{-3}$ & 10 & 88.4 \\
4 & 49.5 & $1.1 \times 10^{-3}$ & 11 & 78.1 \\
5 & 39.7 & $1.1 \times 10^{-3}$ & 10 & 71.0 \\
6 & 29.5 & $1.1 \times 10^{-3}$ & 11 & 65.3 \\
7 & 21.6 & $1.1 \times 10^{-3}$ & 10 & 53.4 \\
8 & 5.0 & $1.3 \times 10^{-3}$ & 11 & 27.0 \\
\hline
\end{tabular}

\subsection{Characterisation of the microstructure of the copolymers}

After reaction, poly(VDF-co-HFP) copolymers were precipitated from cold pentane, leading to viscous oils which were characterised by NMR spectroscopy. As extensively reported by Pianca et al. [11], all ${ }^{19}$ F NMR spectra (Fig. 1) show the presence of signals in the range of -90 to -95 , at $-104,-110,-113,-116$ ppm characteristic of $\mathrm{CF}_{2}$ in VDF units (normal and reversed) [12-14] and at -70, -75, - 119 and $-182 \mathrm{ppm}$ assigned to HFP units. As mentioned by
Schmiegel [15], two consecutive HFP units were not observed, in contrast to the situation previously noted in $\mathrm{R}_{\mathrm{F}}(\mathrm{HFP})_{2} \mathrm{I}$ telomers produced by stepwise telomerisation of HFP with perfluoroalkyl iodides [16].

The mol.\% of VDF in the copolymer was calculated as follows (Eq. (1)), taking into account $I_{-i}$ which represents the integral of the signal centred at $-i \mathrm{ppm}$ :

mol.\% VDF

$$
=\frac{I_{-91}+I_{-93}+I_{-104}+I_{-110}+I_{-113}+I_{-116}}{I_{-91}+I_{-93}+I_{-104}+I_{-110}+I_{-113}+I_{-116}+I_{-119}}
$$

In addition, the defects of chaining are very low (these defects of chaining are the head-to-head VDF units or reversed VDF diad $-\mathrm{CH}_{2} \mathrm{CF}_{2}-\mathrm{CF}_{2} \mathrm{CH}_{2}-$ ), which was deduced from the calculation of $I_{-116} /\left(I_{-91}+I_{-93}+\right.$ $\left.I_{-104}+I_{-110}+I_{-113}+I_{-116}\right)[=3.4 \%]$ from Fig. 1 (the copolymer containing $78.0 \mathrm{~mol} \% \mathrm{VDF})$.

Starting from a VDF mol.\% in the feed of ca. $49.5 \%$, such a value $(78.0 \mathrm{~mol} \% \mathrm{VDF})$ is consistent with those of fluoroelastomers [10,11], taking into account the following reactivity ratios of VDF and HFP:

$r_{\mathrm{VDF}}=6.70, \quad r_{\mathrm{HFP}}=0[10], \quad r_{\mathrm{VDF}}=2.45$ and $r_{\mathrm{HFP}}=0[11]$

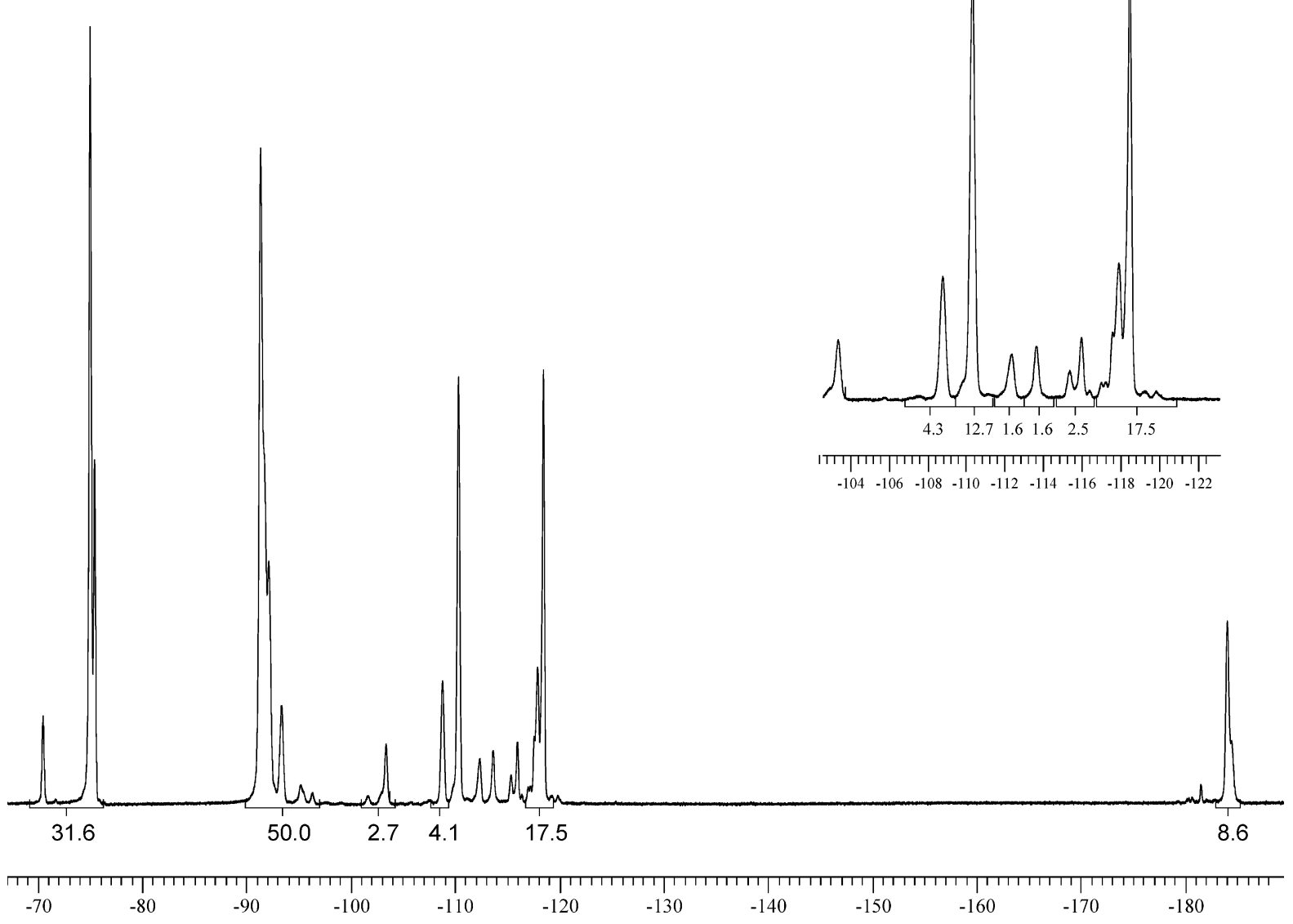

Fig. 1. ${ }^{19}$ F NMR spectrum of poly(VDF-co-HFP) copolymer obtained from the radical copolymerisation of VDF with HFP (molar feed 49.5/50.5) initiated by di-tert-butyl peroxide at $393 \mathrm{~K}$ for $10 \mathrm{~h}$. 
for which these copolymerisations were achieved in emulsion.

Table 3 shows the results of copolymerization and indicates that for the eight copolymerisation reactions, the molar amounts of VDF in the copolymers are always higher than those introduced in the feed, showing that the VDF incorporates the copolymer better than does HFP.

Regarding the ${ }^{1} \mathrm{H}$ NMR spectra of the copolymer, the absence of both the triplet of triplets and the doublet of multiplets centered at 6.2 and $7.0 \mathrm{ppm}$, assigned to $\mathrm{CH}_{2} \mathrm{CF}_{2} \mathrm{H}$ and $-\mathrm{CH}_{2}-\mathrm{CF}\left(\mathrm{CF}_{3}\right) \mathrm{H}$, respectively, indicates the absence of any hydrogen abstraction and hence of any transfer $[12,13,16]$.

Moreover, the copolymerisation of both co-monomers occurred over the entire range of composition used, assuming that no homopolymerisation of VDF occurred under these conditions. On the basis of solubility, it was found that except for the polymer obtained from the radical homopolymerisation of VDF (soluble in dimethyl formamide (DMF), dimethyl sulfoxide (DMSO) and in dimethyl acetamide (DMAc)), all the poly(VDF-co-HFP) copolymers were soluble in acetone, DMF, DMAc, or in DMSO. This also evidences that no PVDF was produced in the copolymerisation.

\subsection{Kinetics of copolymerisation}

Fig. 2 represents the monomer-polymer copolymerisation curve of mol.\% VDF in copolymer versus mol.\% VDF in feed. All points are located above the bisector showing a higher reactivity of VDF than HFP. By nonlinear curve fitting, using the Tidwell and Mortimer method [17], the reactivity ratios of both co-monomers were assessed. We have found:

$r_{\mathrm{VDF}}=2.9 \pm 0.6$ and $r_{\mathrm{HFP}}=0.12 \pm 0.05$ at $393 \mathrm{~K}$

The maximum intervals of confidence calculated according to Carcano et al. [18] seem to be overestimated. The reactivity ratio of HFP was almost nil confirming that this

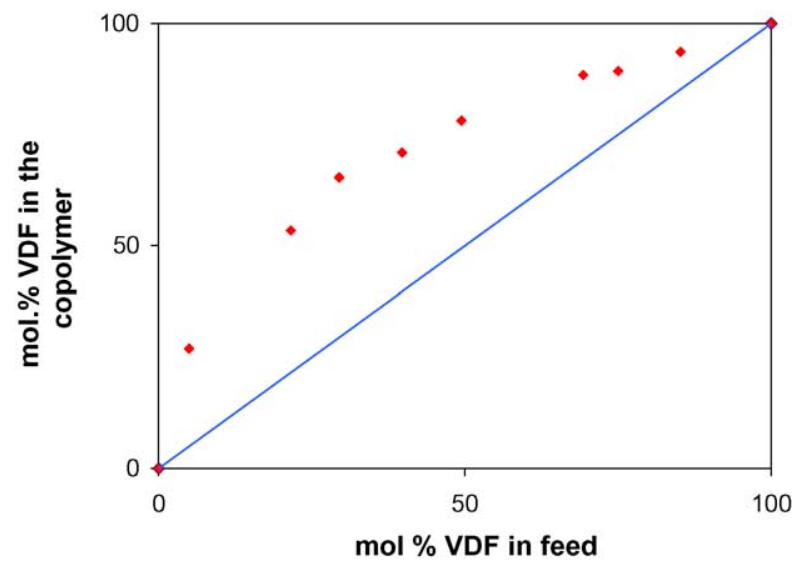

Fig. 2. Polymer/monomer composition curve for the radical copolymerisation of VDF with HFP (initiated by di-tert-butyl peroxide at $393 \mathrm{~K}$ ). fluoroalkene does not homopolymerise. The product $r_{\mathrm{VDF}} \times r_{\mathrm{HFP}}=0.348$, higher than 0 , shows that random copolymers have been formed. Because $r_{\mathrm{A}}>1$ and $r_{\mathrm{B}}<1$ (where A and B represent VDF and HFP, respectively), one can consider that the rate constants $k$ can be compared as follows: $k_{\mathrm{AA}}>k_{\mathrm{AB}} ; k_{\mathrm{BB}}<k_{\mathrm{BA}}$ showing that both radicals mmich $\mathrm{CH}_{2} \mathrm{CF}_{2}{ }^{\bullet}$ and $\operatorname{mm} \mathrm{CF}_{2} \mathrm{CF}^{\bullet}\left(\mathrm{CF}_{3}\right)$ have a high tendency to react with HFP. In addition, the large difference between both reactivity ratios shows that VDF radicals are more reactive than HFP radicals towards the monomer pair.

Table 4 enables the comparison of the reactivity ratios of these couples of monomers to those of other pairs involving VDF [19-39]. The co-monomers were classified according to the number of fluorine atoms or fluorinated groups born by their ethylenic carbon atoms. However, it is rather difficult to compare the behaviour in copolymerisation of all these couples of monomers since their kinetics of copolymerisation were not carried out in the same conditions of initiating systems, temperature, time, and monomer conversions. Furthermore, the interval of confidence is not given for the reactivity ratios of all the comonomers.

A general tendency appears to be that the higher the number of fluorine atoms linked to the ethylenic carbons of the co-monomers, the lower the reactivity of this comonomer, especially when bulky groups are born by the double bond (e.g., perfluoromethyl vinyl ether (PMVE), perfluoropropyl vinyl ether (PPVE), methyl trifluoroacrylate (MTFA), pentafluoropropene (PFP), pentafluoropropene-2acid fluoride, and HFP).

The traditional method for the determination of relative reactivity of a macroradical to several monomers was used. Indeed, it is common to compare the values $1 / r_{\mathrm{A}}=k_{\mathrm{AB}} / k_{\mathrm{AA}}$ as the ratio of rate constants of cross-propagation to that of propagation $\left(k_{\mathrm{AA}}\right)$. Thus, the higher the $1 / r$ value, the more able the radical is to react with the second monomer. Table 4 allows us to suggest the following series of relative reactivities of monomers to $\operatorname{mm} \mathrm{CH}_{2} \mathrm{CF}_{2}{ }^{\bullet}$ radicals: $\mathrm{HFO}<\mathrm{PFP}<\mathrm{HFP}<\mathrm{PMVE}<\mathrm{PPVE}<\mathrm{VDF}<\mathrm{C} 4 \mathrm{Br}<$ TrFE $<$ CTFE (recent value) $\approx$ BrTFE $<$ MDP $<$ MTFA $<$ TFE $<$ FSAc $<$ FAc $<$ VF $\approx$ CTFE (old value) $<$ E.

$Q$ and $e$ values (linked to the resonance and to inductive effects of the monomer, respectively) of HFP can be determined from those of VDF taking into account Alfrey and Price's theory [40], as follows:

$e_{2}=e_{1} \pm\left[-\ln \left(r_{1} \times r_{2}\right)\right]^{1 / 2}$

$Q_{2}=\frac{Q_{1}}{r_{1}} \exp \left[-e_{1}\left(e_{1}-e_{2}\right)\right]$

where $Q_{i}$ and $e_{i}$ represent these parameters and $r_{i}$ the reactivity ratio of monomer $i$.

For fluoromonomers, it is known that $e$ value is always positive since these are electron-withdrawing monomers [1].

However, a low $Q$ value indicates that the system is few stabilised by resonance. According to classic tables [1,41], 
Table 4

Monomer reactivity ratios for the copolymerisation of VDF (A) with other fluoroalkenes (B) (and ethylene (E) and vinyl acetate (VAc))

\begin{tabular}{|c|c|c|c|c|c|}
\hline Monomer B & $r_{\mathrm{A}}$ & $r_{\mathrm{B}}$ & $r_{\mathrm{A}} \mathrm{r}_{\mathrm{B}}$ & $1 / r_{\mathrm{A}}$ & Ref. \\
\hline $\mathrm{H}_{2} \mathrm{C}=\mathrm{CH}_{2}(\mathrm{E})$ & 0.05 & 8.5 & 0.42 & 20.00 & [19] \\
\hline \multirow{2}{*}{$\mathrm{H}_{2} \mathrm{C}=\mathrm{CHOCOCH}_{3}(\mathrm{VAc})$} & -0.40 & 1.67 & -0.67 & -2.5 & {$[20]$} \\
\hline & 0.50 & 2.0 & 1.00 & 2.0 & [21] \\
\hline $\mathrm{H}_{2} \mathrm{C}=\mathrm{C}\left(\mathrm{CF}_{3}\right) \mathrm{CO}_{2} \mathrm{H}(\mathrm{TFMAA})$ & 0.33 & 0 & 0 & 3.03 & {$[22]$} \\
\hline \multirow[t]{2}{*}{$\mathrm{FCH}=\mathrm{CH}_{2}(\mathrm{VF})$} & 0.17 & $4.2-5.5$ & $0.71-0.94$ & 5.88 & {$[23]$} \\
\hline & $0.20-0.43$ & $3.8-4.9$ & $0.76-2.11$ & $2.33-5.00$ & [24] \\
\hline $\mathrm{H}_{2} \mathrm{C}=\mathrm{CFCF}_{2} \mathrm{OR}_{\mathrm{F}}(\mathrm{MDP})$ & 0.38 & 2.41 & 0.92 & 2.63 & {$[25]$} \\
\hline $\mathrm{F}_{2} \mathrm{C}=\mathrm{CFH}(\mathrm{TrFE})$ & 0.70 & 0.50 & 0.35 & 1.43 & [26] \\
\hline $\mathrm{F}_{2} \mathrm{C}=\mathrm{CHCF}_{3}(\mathrm{PFP})$ & 9.0 & 0.06 & 0.54 & 0.11 & [27] \\
\hline $\mathrm{F}_{2} \mathrm{C}=\mathrm{CHC}_{6} \mathrm{~F}_{13}(\mathrm{HFO})$ & 12.0 & 0.90 & 10.80 & 0.08 & [28] \\
\hline \multirow[t]{2}{*}{$\mathrm{CFCl}=\mathrm{CF}_{2}(\mathrm{CTFE})$} & 0.73 & 0.75 & 0.55 & 1.37 & [29] \\
\hline & 0.17 & 0.52 & 0.09 & 5.88 & {$[30]$} \\
\hline $\mathrm{CFBr}=\mathrm{CF}_{2}(\mathrm{BrTFE})$ & 0.43 & 1.46 & 0.63 & 2.33 & [29] \\
\hline \multirow[t]{2}{*}{$\mathrm{CF}_{2}=\mathrm{CF}_{2}(\mathrm{TFE})$} & 0.23 & 3.73 & 0.86 & 4.35 & {$[11,29]$} \\
\hline & 0.32 & 0.28 & 0.09 & 3.13 & {$[31]$} \\
\hline \multirow[t]{3}{*}{$\mathrm{CF}_{3}-\mathrm{CF}=\mathrm{CF}_{2}(\mathrm{HFP})$} & 6.70 & 0 & 0 & 0.15 & {$[10]$} \\
\hline & 2.45 & 0 & 0 & 0.40 & {$[11]$} \\
\hline & 2.90 & 0.12 & 0.35 & 0.34 & This work \\
\hline $\mathrm{F}_{2} \mathrm{C}=\mathrm{CFOCF}_{3}(\mathrm{PMVE})$ & 3.40 & 0 & 0 & 0.29 & {$[32]$} \\
\hline $\mathrm{F}_{2} \mathrm{C}=\mathrm{CFOC}_{3} \mathrm{~F}_{7}(\mathrm{PPVE})$ & 1.15 & 0 & 0 & 0.86 & [32] \\
\hline $\mathrm{F}_{2} \mathrm{C}=\mathrm{CFO}(\mathrm{HFP}) \mathrm{OC}_{2} \mathrm{~F}_{4} \mathrm{SO}_{2} \mathrm{~F}(\mathrm{PSEPVE})$ & 0.57 & 0.07 & 0.04 & 1.75 & [1] \\
\hline $\mathrm{CF}_{2}=\mathrm{CFCH}_{2} \mathrm{OH}(\mathrm{FA} 1)$ & 0.83 & 0.11 & 0.09 & 1.02 & [33] \\
\hline $\mathrm{CF}_{2}=\mathrm{CF}\left(\mathrm{CH}_{2}\right)_{2} \mathrm{Br}(\mathrm{C} 4 \mathrm{Br})$ & 0.96 & 0.09 & 0.09 & 1.00 & [34] \\
\hline $\mathrm{CF}_{2}=\mathrm{CF}\left(\mathrm{CH}_{2}\right)_{3} \mathrm{OAc}(\mathrm{FAc})$ & 0.17 & 3.26 & 0.59 & 5.56 & {$[35]$} \\
\hline $\mathrm{F}_{2} \mathrm{C}=\mathrm{CF}\left(\mathrm{CH}_{2}\right)_{3} \mathrm{SAc}(\mathrm{FSAc})$ & 0.60 & 0.41 & 0.25 & 4.07 & {$[36]$} \\
\hline $\mathrm{CF}_{2}=\mathrm{CFCO}_{2} \mathrm{CH}_{3}(\mathrm{MTFA})$ & 0.30 & 0 & 0 & 3.33 & [37] \\
\hline $\mathrm{F}_{2} \mathrm{C}=\mathrm{C}\left(\mathrm{CF}_{3}\right) \mathrm{COF}$ & 7.60 & 0.02 & 0.15 & 0.13 & [38] \\
\hline $\mathrm{F}_{2} \mathrm{C}=\mathrm{C}\left(\mathrm{CF}_{3}\right) \mathrm{OCOC}_{6} \mathrm{H}_{5}$ & 0.77 & 0.11 & 0.08 & 1.30 & [39] \\
\hline
\end{tabular}

the value of HFP is among the lowest, confirming that this monomer is poorly reactive; this may explain why it does not homopolymerise $\left(r_{\mathrm{HFP}} \approx 0\right)$.

Taking into account that $e_{\mathrm{VDF}}=0.40$ [31] or 0.50 [41] and $Q_{\mathrm{VDF}}=0.008$ [31] or 0.015[41], two $e$ and $Q$ values have been assessed for HFP. We have found that

$e_{\mathrm{HFP}}=1.44$ or 1.54 and $Q_{\mathrm{HFP}}=0.002$ or 0.009

The $e_{\mathrm{B}}\left(\mathrm{HFP}\right.$ ) value is positive, $e_{\mathrm{B}}=1.44$ (from $e_{\mathrm{A}}=0.40$ ) or $e_{\mathrm{B}}=1.54$ (from $e_{\mathrm{A}}=0.50$ ) while those of VDF are lower than that of trifluoroethylene $(\mathrm{TrFE})\left(e_{\mathrm{TrFE}}=1.15\right)[1,41]$, due to the lower electron-withdrawing effect because of both hydrogen atoms substituent versus the fluorine atom in TrFE. The $e$-values for VF given in the literature are rather different, and even negative [23] ( $e_{\mathrm{VF}}=-0.50$ [23] or -0.80 [24]). Thus, in the latter case, the hydrogen atom seems to act as an electron-donating substituent. But for HFP as for other co-monomers, the $e$-value is always positive due to the electron-withdrawing effect of fluorine atoms. Thus, mainly random copolymerisation between VDF and HFP is expected.

The $Q$-value of HFP is very small $(0.002-0.009)$ which is good evidence for the poor ability of a fluorine atom for resonance stabilization of the radical on the adjacent carbon atom. Hence, the HFP radical has to be highly unstable.
2.3. Assessment of the glass transition temperature $\left(T_{g}\right)$ of poly(VDF-co-HFP) copolymers

It was first observed that all copolymers analysed by differential scanning calorimetry (DSC) showed a sharp transition from the glassy to viscoelastic zone, as noted by the presence of only one sharp $T_{\mathrm{g}}$. Although DSC was also carried out on all these samples from 343 to $448 \mathrm{~K}$, the presence of crystallisation or melting temperatures was observed for copolymers containing a high VDF percentage.

The $T_{\mathrm{g}}$ values range between 232.9 and $261.4 \mathrm{~K}$ (Table 5) indicates that the copolymers exhibit amorphous and elastomeric behaviours, as expected. Interestingly, it is observed that the higher the VDF content, the lower the $T_{\mathrm{g}}$, since, as expected, the branched $-\mathrm{CF}_{3}$ side group (arising

Table 5

Glass transition temperatures of poly(VDF-co-HFP) copolymers

\begin{tabular}{lll}
\hline Experiment no. & \% VDF in the copolymer & $T_{\mathrm{g}}(\mathrm{K})$ \\
\hline 1 & 27.0 & 261.4 \\
2 & 53.4 & 245.9 \\
3 & 71.0 & 239.6 \\
4 & 78.1 & 237.4 \\
5 & 88.4 & 235.4 \\
6 & 89.3 & 232.9 \\
\hline
\end{tabular}


from HFP) about the polymeric backbone induces an increase of the $T_{\mathrm{g}}$ values.

Hence, it was worth determining the $T_{\mathrm{g}}$ of the homopolymer of HFP. To our knowledge, the only homopolymerisation of HFP was achieved by Eleuterio and Pensak [42], initiated by severe conditions of ultra-high pressure.

Usually, several relationships for the $T_{\mathrm{g}}$ of blends are used in the literature [43-47]. We have chosen Fox's [44] and Johnston's [45] relationships:

$\frac{1}{T_{\mathrm{g}}}=\frac{w_{1}}{T_{\mathrm{g}_{1}}}+\frac{w_{2}}{T_{\mathrm{g}_{2}}}$

where $T_{\mathrm{g}}, T_{g_{1}}$ and $T_{g_{2}}$ represent the glass transition temperatures (in Kelvin) of the copolymer, of PVDF and of poly(HFP) while $w_{1}$ and $w_{2}$ stand for the initial massic percentages of VDF and HFP, respectively.

This relationship is usually successful for high molecular weights and although we could not assess those of these copolymers (lack of standards), it was found that no transfer was observed in the course of the copolymerisations. This was checked by the absence of both the triplet of triplets centred at $6.3 \mathrm{ppm}$ and of doublet of multiplets at $-114.8 \mathrm{ppm}$ in the ${ }^{1} \mathrm{H}$ and ${ }^{19} \mathrm{~F}$ NMR spectra, respectively.

This law can be written as follows:

$w_{2}=T_{\mathrm{g}_{2}}\left(\frac{1}{T_{\mathrm{g}}}-\frac{w_{1}}{T_{\mathrm{g}_{1}}}\right)$

Thus, plotting $w_{2}$ versus $\left(\frac{1}{T_{\mathrm{g}}}-\frac{w_{1}}{T_{\mathrm{g}_{1}}}\right)$ leads to a straight line, the slope of which represents the glass transition temperature of poly(HFP) (Fig. 3).

Hence, poly(HFP) has a $T_{\mathrm{g}}$ of $264.47 \mathrm{~K}$ which is much lower than that determined by Bonardelli et al. [48] (Table 6).

On the other hand, the $T_{\mathrm{g}}$ value of this homopolymer is not surprising when compared to that of poly $\left(\mathrm{H}_{2} \mathrm{C}=\mathrm{CFCF}_{3}\right)$ $\left(T_{\mathrm{g}}=315 \mathrm{~K}\right)$ [47].

But, another relationship has also been used as Johnston's equation [45] which seems more rigorous than the one above

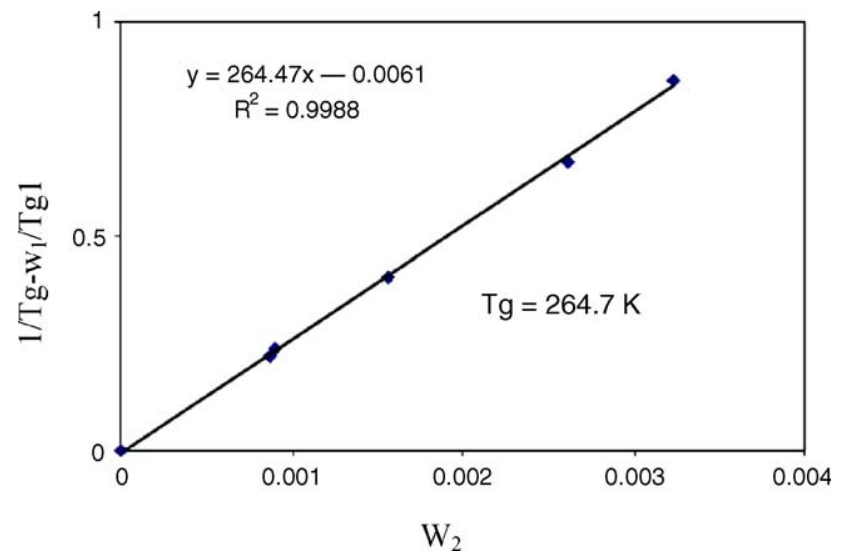

Fig. 3. $1 / T_{\mathrm{g}}-w_{1} / T_{\mathrm{g}}$ vs. $w_{2}$ for the assessment of the $T_{\mathrm{g}}$ of poly(HFP) according to Fox's relationship [44].
Table 6

Results of different glass transition temperatures of poly(HFP) compared to those of the literature

\begin{tabular}{ll}
\hline$T_{\mathrm{g}}$ of poly(HFP) $\left({ }^{\circ} \mathrm{C}\right)$ & Reference \\
\hline 284 & {$[50]$} \\
425 & {$[47]$} \\
433 & {$[48]$} \\
265 & Our work (from Fox' relationship) \\
270 & Our work (from Johnson's relationship) \\
287 & Our work (from Johnson's relationship) \\
\hline
\end{tabular}

because it takes into account the affinity of monomers, considering the probabilities of additions, as follows:

$\frac{1}{T_{\mathrm{g}}}=\frac{w_{\mathrm{A}} P_{\mathrm{AA}}}{\left(T_{\mathrm{g}}\right)_{\mathrm{AA}}}+\frac{w_{\mathrm{B}} P_{\mathrm{BB}}}{\left(T_{\mathrm{g}}\right)_{\mathrm{BB}}}+\frac{w_{\mathrm{A}} P_{\mathrm{AB}}+w_{\mathrm{B}} P_{\mathrm{BA}}}{\left(T_{\mathrm{g}}\right)_{\mathrm{AB}}}$

where $P_{\mathrm{AA}}, P_{\mathrm{BB}}, P_{\mathrm{AB}}$ and $P_{\mathrm{BA}}$ represent the conditional probabilities of addition.

$$
\begin{gathered}
P_{\mathrm{AB}}=\frac{1}{1+r_{\mathrm{A}} X}, \quad P_{\mathrm{AA}}=1-P_{\mathrm{AB}}, \\
P_{\mathrm{BA}}=\frac{1}{1+r_{\mathrm{B}} / X}, \quad P_{\mathrm{BB}}=1-P_{\mathrm{BA}}
\end{gathered}
$$

where $r_{\mathrm{A}}$ and $r_{\mathrm{B}}$ represent the respective reactivity ratios.

For each composition, $X$, which stands for the molar ratio (A/B) has to be calculated.

By plotting $w_{\mathrm{B}} P_{\mathrm{BB}}$ versus $\left[1 / T_{\mathrm{g}}-\left(w_{\mathrm{A}} P_{\mathrm{AB}}+w_{\mathrm{B}} P_{\mathrm{BA}}\right) /\right.$ $\left.T_{\mathrm{gAB}}-w_{\mathrm{A}} P_{\mathrm{AA}} / T_{\mathrm{gAA}}\right]$, the slope supplies the glass transition temperature of poly(HFP). $T_{\mathrm{gAB}}$ represents the glass transition temperature of the alternating poly(VDF-alt-HFP) copolymer. According to the literature, such a value worths $273 \mathrm{~K}$ [48] but from the results mentioned above it is considered as $246 \mathrm{~K}$. Such a latter value differs from the former because the copolymers were synthesised under different experimental conditions. Hence, the resulting copolymers were endowed with various molar masses, since from emulsion copolymerisation, high molar mass-polymers are usually produced in contrast to those obtained from solution copolymerisation.

Figs. 4 and 5 represent the straight lines obtained from the equation above in the case where the $T_{\mathrm{g}}$ of poly(VDF-alt-

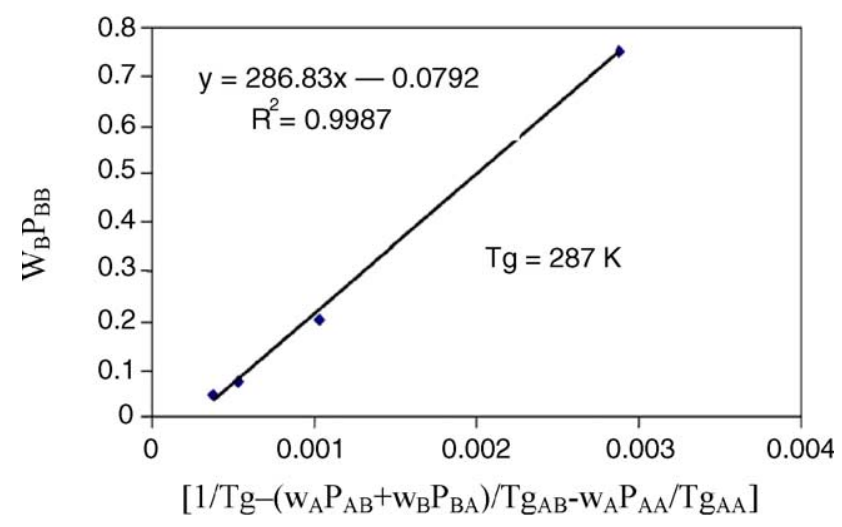

Fig. 4. Assessment of the $T_{\mathrm{g}}$ of poly(HFP) according to Johnston's equation [45] and $\left(T_{\mathrm{g}}\right)_{\mathrm{AB}}=273 \mathrm{~K}$, by plotting $w_{\mathrm{B}} P_{\mathrm{BB}}$ vs. $\left[1 / T_{\mathrm{g}}-\left(w_{\mathrm{A}} P_{\mathrm{AB}}+w_{\mathrm{B}} P_{\mathrm{BA}}\right) /\right.$ $\left.T_{\mathrm{gAB}}-w_{\mathrm{A}} P_{\mathrm{AA}} / T_{\mathrm{gAA}}\right]$. 


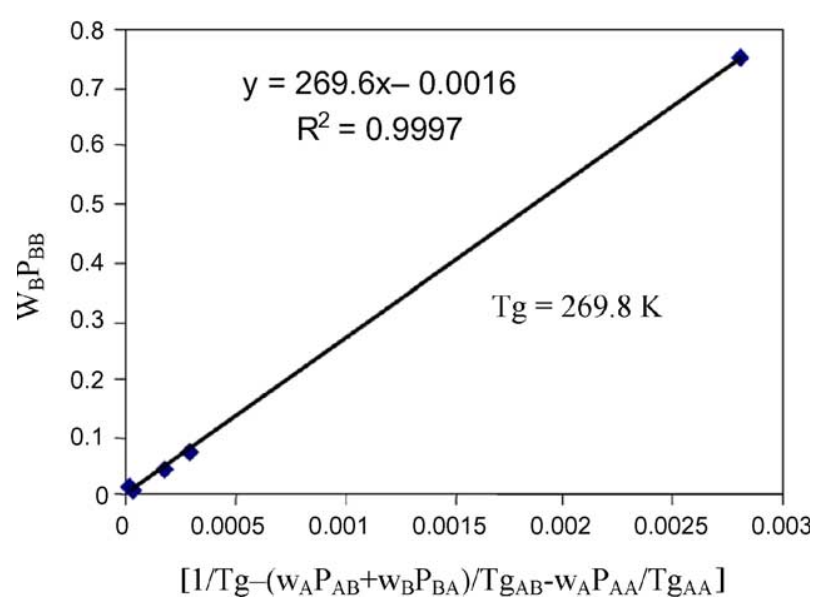

Fig. 5. Determination of the $T_{\mathrm{g}}$ of poly(HFP) according to Johnston's relationship [45] using $\left(T_{\mathrm{g}}\right)_{\mathrm{AB}}=246 \mathrm{~K}$, by plotting $w_{\mathrm{B}} P_{\mathrm{BB}}$ vs. [1/ $\left.T_{\mathrm{g}}-\left(w_{\mathrm{A}} P_{\mathrm{AB}}+w_{\mathrm{B}} P_{\mathrm{BA}}\right) / T_{\mathrm{gAB}}-w_{\mathrm{A}} P_{\mathrm{AA}} / T_{\mathrm{gAA}}\right]$.

HFP) copolymer worths 273 and $246 \mathrm{~K}$, respectively. It is normal to find a value for poly(HFP) (ranging from 270 to $287 \mathrm{~K}$, respectively) much lower than that assessed by Brown and Wall [49] and Bonardelli et al. [48] who carried out emulsion copolymerisation. However, $T_{\mathrm{g}}$ value of poly(HFP) calculated from Johnston's relationship (287 K) is close to that assessed by Rodriguez [50] (284 K, Table 6). This difference can be explained by the introduction of both the probabilities of addition and the reactivity ratios in that equation. Indeed, drifts in the determination of the reactivity ratios can also be observed.

In fact, the poly(VDF-co-HFP) copolymers obtained by solution polymerisation show lower molar masses than those achieved from emulsion copolymerisation.

\section{Conclusion}

The radical copolymerisation of vinylidene fluoride (VDF) with hexafluoropropene (HFP) was studied in a wide range of initial monomer compositions. ${ }^{19} \mathrm{~F}$ NMR spectroscopy enabled the copolymer compositions to be determined. The reactivity ratios $r_{i}$ of co-monomers were calculated by the Tidwell and Mortimer method, showing that, as expected, HFP was less reactive than VDF $\left(r_{\mathrm{VDF}}=2.9\right.$ and $r_{\mathrm{HFP}}=0.12$ at $\left.393 \mathrm{~K}\right)$. These values demonstrate that a random copolymerisation occurred. For HFP mol. contents higher than $15 \%$, the resulting copolymers exhibit amorphous behaviour even with rather low $T_{\mathrm{g}}$, confirming potential applications of these materials at low temperatures. Extrapolation of these results, taking into account the classical relationship of $T_{\mathrm{g}}$, could enable the $T_{\mathrm{g}}$ of poly(HFP) to be assessed, although the relationship of determination of the glass transition temperatures have led to various values from Fox's or Johnston's equations. However, the second law led to a value close to that observed by Rodriguez [50].
Nevertheless, lowering the $T_{\mathrm{g}}$ of poly(VDF-co-HFP) fluoroelastomers below $241 \mathrm{~K}$ is still a challenge and such a research could be quite attractive for industrial and academic researchers.

\section{Experimental}

Vinylidene fluoride (VDF) and HFP were kindly donated by Solvay S.A., whereas di-tert-butyl peroxide and acetonitrile (freshly distilled over calcium hydride) were supplied by Aldrich and SDS, respectively.

Radical copolymerisations of VDF and HFP were performed in thick borosilicate Carius tubes in a batch process (length: $130 \mathrm{~mm}$, internal diameter: $10 \mathrm{~mm}$, thickness: $2.5 \mathrm{~mm}$, for a total volume of $8 \mathrm{~cm}^{3}$ ). After having placed the initiator (ca. 1 mol.\% to the monomer mixture), and acetonitrile in the tube, it was connected to a vacuum line and purged several times by evacuating and flushing with helium. After a minimum of six thaw-freeze cycles performed to remove oxygen, VDF was trapped under vacuum in the tube frozen in liquid nitrogen, after a release in an intermediate metallic container calibrated in pressure. The required amount of VDF (0.147$1.324 \pm 0.008 \mathrm{~g}$ ) introduced into the tube was assessed by the relative drop of pressure in this release container, initially fed from a cylinder of $300 \mathrm{~g}$ of VDF (Table 3). A beforehand calibration curve 'weight of trapped VDF (in g) versus drop of pressure (in bar)' was consulted (for $1.324 \mathrm{~g}$ of VDF, a difference of pressure of 0.90 bar was required). The same procedure was achieved for introducing HFP (from a cylinder containing $150 \mathrm{~g}$ of that monomer) in the frozen tube (after purging and flushing the tubings and connections). As above, the accurate introduction of HFP was achieved by taking into account a beforehand calibration curve 'weight of trapped HFP (in g) versus drop of pressure (in bar)' (in fact, for $1.000 \mathrm{~g}$ of HFP introduced, a difference of pressure of 0.25 bar was necessary). The tube, under vacuum and immersed in liquid nitrogen, was sealed and placed into a shaking oven at $393 \mathrm{~K}$ for $10 \mathrm{~h}$. In such a reaction time, it was considered that the VDF conversion was ca. 10-12\% that was suitable for satisfactory conditions of kinetics of copolymerisation although VDF conversion was not assessed because of the lack of accuracy in weighing the opened frozen tube. Nevertheless, it was assumed that this conversion rate must be higher than that of HFP, taking into account both known reactivity ratios.

The reactant weights used in these eight copolymerisation reactions are listed in Table 3.

After copolymerisation, the tube was frozen in liquid nitrogen and then opened, and the total product mixture added dropwise into $50 \mathrm{ml}$ of vigorously stirred cold pentane. This enabled the copolymer to be separately phased as a sticky oil (copolymer containing HFP contents higher than $15 \mathrm{~mol} \%$ ), wax or powder (for copolymers with high 
VDF contents) deposited along the walls of the container. After removing the pentane solution, the remaining copolymer was dried at $80^{\circ} \mathrm{C}$ under $10^{-2}$ Torr until constant weight was achieved.

The compositions of the copolymers (i.e., the content of VDF and HFP in copolymers) were determined by NMR spectroscopy at room temperature. The ${ }^{1} \mathrm{H}$ and ${ }^{19} \mathrm{~F}$ NMR spectra were recorded on a Bruker AC-200 or Bruker AC-250 instruments using deuterated acetone, and tetramethyl silane (TMS) or $\mathrm{CFCl}_{3}$, as the solvent and internal reference, respectively. The experimental conditions for recording ${ }^{1} \mathrm{H}$ (or ${ }^{19} \mathrm{~F}$ ) NMR spectra were the following: flip angle $90^{\circ}\left(30^{\circ}\right)$; acquisition time $4.5 \mathrm{~s}(0.7 \mathrm{~s})$; pulse delay $2 \mathrm{~s}$ $(5 \mathrm{~s}) ; 64$ (128) scans and pulse width of $5 \mu \mathrm{s}$ for ${ }^{19} \mathrm{~F}$ NMR. The letters $\mathrm{s}, \mathrm{t}$ and $\mathrm{m}$ represent singlet, triplet and multiplet, respectively.

Differential scanning calorimetry (DSC) measurements were conducted using a Perkin-Elmer Pyris 1 instrument connected to a micro-computer; the apparatus was calibrated with indium and with n-decane. After its insertion into the DSC apparatus, the sample was initially cooled to $168 \mathrm{~K}$ for $15 \mathrm{~min}$. The first scan was made at a heating rate of $40{ }^{\circ} \mathrm{C} \mathrm{min}{ }^{-1}$, up to $353 \mathrm{~K}$, where it remained for $2 \mathrm{~min}$. It was then cooled to $168 \mathrm{~K}$ at a rate of $320{ }^{\circ} \mathrm{C} \mathrm{min}^{-1}$. It was again left for $10 \mathrm{~min}$ at that temperature before a second scan was started at a heating rate of $20{ }^{\circ} \mathrm{C} \mathrm{min}{ }^{-1}$. Finally, another cycle was performed and a third scan at a heating rate of $20{ }^{\circ} \mathrm{C} \mathrm{min}-1$ was initiated, giving the values of $T_{\mathrm{g}}$ reported herein, taken at the half-height of the heat capacity jump of the glass transition. A second series of scanning was also attempted from 343 to $448 \mathrm{~K}$ and the thermograms of all the samples containing a high VDF amount show crystallisation or melting peaks.

\section{Acknowledgments}

The authors thank the Solvay Company (Tavaux, France) for the gifts of VDF and HFP. Help from Professor Fruchier (Head of NMR at ENSCM) for recording high-resolution NMR spectra and for fruitful discussions was also appreciated.

\section{References}

[1] B. Ameduri, B. Boutevin, Well-Architectured Fluoropolymers: Synthesis, Properties and Applications, Elsevier, Amsterdam, 2004.

[2] C. Tournut, Makromol. Chem. Macro. Symp. 82 (1994) 99.

[3] C. Tournut, Thermoplastic copolymers of vinylidene fluoride, in: J. Scheirs (Ed.), Modern Fluoropolymers, Wiley, New York, 1997, pp. 577-595(Chapter 31).

[4] V. Arcella, R. Ferro, Fluorocarbon elastomers, in: J. Scheir (Ed.), Modern Fluoropolymer, Wiley, New York, 1997, pp. 71-90(Chapter 2).

[5] A. Van Cleef, Fluoroelastomers, in: J. Scheir (Ed.), Modern Fluoropolymers, Wiley, New York, 1997, pp. 597-614(Chapter 32).
[6] D.A. Seiler, PVDF in the chemical process industry, in: J. Scheirs (Ed.), Modern Fluoropolymers, Wiley, New York, 1997, pp. 487506(Chapter 25).

[7] (a) A.L. Logothetis, Progr. Polym. Sci. 14 (1989) 251-296; (b) A.L. Logothetis, Fluoroelastomers, in: R.E. Banks, B.E. Smart, J.C. Tatlow (Eds.), Organofluorine Chemistry: Principles and Commercial Applications, 373-395 (1994) (Chapter 16).;

(c) D. Cook, M. Lynn, Rapra Review Reports, vol. 3, Report 32, Shrewsbury, 1995, pp. 1-27.;

(d) B. Ameduri, B. Boutevin, G. Kostov, Prog. Polym. Sci. 26 (2001) 105-187.

[8] (a) E. Hull, B.V. Jonhson, I.P. Rodricks, J.B. Staley, THV Fluoroplastics, in: J. Scheirs (Ed.), Modern Fluoropolymers, 1997, pp. 257270 (Chapter 13):

(b) B. Ameduri, B. Boutevin, J. Fluorine Chem., Proceedings of the 14th European Symposium in Fluorine Chemistry, Poznan, Poland, July $11-16$, 2004, in press.;

(c) M. Apostolo, J. Fluorine Chem., Proceedings of the 14th European Symposium on Fluorine Chemistry, Poznan, Poland, July 11-16, 2004, in press.

[9] S. Dixon, D.R. Rexford, J.S. Rugg, Ind. Eng. Chem. 49 (1957) 1687.

[10] G. Moggi, P. Bonardelli, S. Russo, Conv. Ital. Sci. Macromol., 6th 2 (1983) 405-408.

[11] M. Pianca, P. Bonardelli, M. Tato, G. Cirillo, G. Moggi, Polymer 28 (1987) 224-230.

[12] J. Guiot, B. Ameduri, B. Boutevin, Macromolecules 35 (2002) 8694 8707.

[13] (a) M. Duc, B. Ameduri, B. Boutevin, M. Kharroubi, J.-M. Sage, Macromol. Chem. Phys. 199 (1998) 1271-1289;

(b) M. Pianca, E. Barchiesi, G. Esposto, S. Radice, J. Fluorine Chem. 95 (1999) 71-84.

[14] B. Ameduri, C. Ladaviere, F. Delolme, B. Boutevin, Macromolecules 37 (2004) 7602-7609.

[15] (a) W.W. Schmiegel, Kaut. Gumm. Kunstst. 31 (1978) 137-148;

(b) W.W. Schmiegel, Angewandte Makromolekulare Chemie 76/77 (1979) 39-65.

[16] J. Balague, B. Ameduri, B. Boutevin, G. Caporiccio, J. Fluorine Chem. 74 (1995) 49.

[17] P.W. Tidwell, G.A. Mortimer, J. Polym. Sci. A: Gen. Pap. 3 (1965) 369-387.

[18] D. Carcano, M. Modena, M. Ragazzini, O. Pilatio, Chim. Ind. 6 (1971) 547.

[19] A.D. Sorokin, E.V. Volkova, R.A. Naberezhnykh, Radiat. Khim. 2 (1972) 295-297.

[20] B. Baradie, M.S. Shoichet, Macromolecules 35 (2002) 3569-3575.

[21] V. Panchalingam, J.R. Reynolds, J. Polym. Sc. Part C: Polym. Lett. 27 (1989) 201

[22] R. Souzy, B. Ameduri, B. Boutevin, Macromol. Chem. Phys. 4 (2004) 476-485.

[23] D. Sianesi, G. Caporiccio, J. Polym. Sci. A1: Polym. Chem. 6 (1968) 335-339.

[24] G. Caporiccio, D. Sianesi, Chim. Ind. (Milan, Italy) 52 (1970) 37-42.

[25] B. Ameduri, G. Bauduin, J. Polym. Sci. A: Polym. Chem. 41 (2003) 3109-3121.

[26] T. Yagi, M. Tatemoto, Polym. J. (Tokyo, Japan) 11 (1979) 429-436.

[27] K.U. Usmanov, A.A. Yul'chibaev, N. Mukhamadaliev, T.K. Sarros, Izvestiya Vysshikh Uchebnykh Zavedenii, Khimiya i Khimicheskaya Tekhnologiya 18 (1975) 464-466 (Chem. Abstr. 83, 28687).

[28] B. Otazaghine, B. Ameduri, Presented at the 16th International Symposium in Fluorine Chemistry, Durham, United Kingdom, July 16-20, 2000 (oral communication B11).

[29] G. Moggi, P. Bonardelli, J.C.J. Bart, J. Polym. Sci., Polym. Phys. 22 (1984) 357-365.

[30] R.E. Dohany, A.A. Dukert, S.S. Preston, Encycl. Polym. Sci. Technol. 17 (1989) 532-547.

[31] R.A. Naberezhnykh, A.D. Sorokin, E.V. Volkova, A.V. Fokin, Izvestiya Akademii Nauk SSSR, Seriya Khimicheskaya (1974) 232-233. 
[32] A. Manseri, B. Ameduri, M. Boucher, Presented at the 15th Winter Fluorine Conference, Saint Petersburg Beach, FL, 2001, pp. 14-19, Communication \#22, Eur. Polym. J. (submitted).

[33] J. Guiot, B. Ameduri, B. Boutevin, J. Polym. Sci. A: Polym. Chem. 40 (2002) 3634-3643.

[34] J. Guiot, M.A. Neouze, L. Sauguet, B. Ameduri, B. Boutevin, J. Polym. Sci. A: Polym. Chem., in press.

[35] B. Ameduri, G. Bauduin, B. Boutevin, G. Kostov, P. Petrova, Macromolecules 32 (1999) 4544-4550.

[36] B. Ameduri, B. Boutevin, G.K. Kostov, P. Petrova, Designed Monomers Polym. 2 (1999) 267-285.

[37] R. Souzy, J. Guiot, B. Ameduri, B. Boutevin, O. Paleta, Macromolecules 36 (2003) 9390-9395.

[38] S.G. Khodzhaev, F.Z. Yusupbekova, A.A. Yul'chibaev, Sbornik Nauchnykh Trudov - Tashkentskii Gosudarstvennyi Universitet im V. I, Lenina 667 (1981) 34-48 (Chem. Abstr. 97,163545).

[39] J. Guiot, B. Ameduri, B. Boutevin, T. Lannuzel, Eur. Polym. J. 39 (2003) 887-896.

[40] T. Alfrey, C.C. Price, J. Polym. Sci. A: Polym. Chem. 2 (1947) 101123.
[41] R.Z. Greenley, $Q$ and $e$ values for free radical copolymerisations of vinyl monomer and telogens, in: J. Brandrup, E.H. Immergut (Eds.), Polymer Handbook, 3rd ed. Wiley, New York, 1989, p. 267;

R.Z. Greenley, $Q$ and $e$ values for free radical copolymerisations of vinyl monomer and telogens, 4th ed. in: J. Brandrup, E.H. Immergut (Eds.), Polymer Handbook, II, Wiley, New York, 1999, p. 309.

[42] H.S. Eleuterio, D. Pensak, in: Proceedings of the 13th European Symposium on Fluorine Chemistry, Bordeaux, 15-20 July, 2001, oral communication C-2.

[43] M. Gordon, J.S. Taylor, J. Appl. Chem. 2 (1952) 493-499.

[44] T.G. Fox, Bull. Am. Phys. Soc. 1 (1956) 123-129.

[45] N.W. Johnston, J. Macromol. Sci. Rev. Macromol. Chem. 14B (1976) 215-222.

[46] P.R. Couchman, Nature 298 (1982) 729-731.

[47] D.W. Brown, L.A. Wall, J. Polym. Sci. Part A-2 7 (1969) 601-607.

[48] P. Bonardelli, G. Moggi, A. Turturro, Polymer 27 (1986) 905-909.

[49] D.W. Brown, L.A. Wall, J. Polym. Sci. A 1 (1968) 1367-1379.

[50] F. Rodriguez, Properties of Polymers Systems, 4th ed. Taylor \& Francis, Washington, 1994. 